\title{
The unusual suspect
}

\section{p53の思いがけない役割}

\author{
Colin L. Stewart
}

p53 タンパク質は腫瘍抑制因子として、がんを防ぐ機能が詳しく研究されている。このタン パク質が、マウスにおける胚の着床の制御に不可欠な生理的役割も果たしていることが明らか になった。

Nature Vol.450 (619)/ 29 November 2007

「ゲノムの番人」と称される p53 タンパク質は、細胞に あるタンパク質の「セレブ」である。医学関係文献デー タベースであるPubMed でp53を検索すると、ヒット 件数は 45,000 件を超え、その大半は、p 53 がストレ スによるDNA 損傷の影響から細胞を守る役割について 取り上げたものである。腫瘍形成を防ぐのに p53 が重 要な役割を果たしていることを考元ると、p53を欠損し たマウスの大部分が正常に発生し、高歯になってから 腫瘍が原因で死亡するという知見は意外だった ${ }^{1}$ 。それ ばかりでなく、2007 年の Nature 11 月 29 日号で Hu たち ${ }^{2}$ は、この有名な転写因子が、雌マウスの受胎能(妊 性）の制御に不可欠だという、まったく予想外の役割を もっていることを明らかにした。

受精後、発生初期の胚である肧盤胞は、母体の子宮 と物理的に接着する。着床とよばれるこの現象は、高 度に統制されており、大部分の哺乳類の生殖において 不可欠な段階の 1 つである。着床が成立すると胎盤の 形成が始まり、胎盤のおかげで胎児は出産まで子宮内 で成長し、発育できる。子宮は胚盤胞の受け入れを可 能にするために、着床の前に細胞の増殖と分化を何回 も繰り返す。こうした事象は主に、卵巣ステロイドホル モンであるエストロゲン E 2 とプロゲステロン P4 の直接 的な作用によって制御されており ${ }^{3} 、 \mathrm{E} 2$ や P4 はさらに、 多数の成長因子や免疫関与因子夕ンパク質（サイトカ イン類）の局所での産生を誘導する ${ }^{4}$ 。

これらの因子の中でサイトカインの LIF（白血病抑制 因子）は、マウスの肧性幹細胞 (ES 細胞) の維持に 必須であることから、最初に哺乳類の発生と関係づけら
れた。LIF は、子宮内膜腺によって産生・分泌される 多くのタンパク質のうちの1つである。さまざまな哺乳 類において、LIF の発現量は着床開始時に最も高くな る ${ }^{5}$ 。実際、子宮の内壁を覆う上皮細胞が LIF にさら されなければ、着床は起こらない ${ }^{6}$ (図 1)。また、LIF を欠損した雌マウスは、胚盤胞が正常に発生するもの の妊娠はできない。しかし LIF 欠損型の雌マウスでも、 通常の着床予定日（マウスでは妊娠 4 日目）にLIFを 1 回注射すると着床が開始し、その後の肧発生は正常 に進行して出産に至る7。

Hu たち ${ }^{2}$ は今回、p53 が子宮内での LIF 発現の制 御、ひいては雌の繁殖能力に重要な役割を果たしてい ることを明らかにした。p53を欠損した雌マウスでは受 胎能が低いが雄マウスではそうではないことに、Huた ちは興味をもった。そして、p53 欠損型の雌マウスでは、 生じた健康な肧の数には影響はなかったが、着床でき た胚の数が少ないことに気づいた。Huたちは、p53が マウスの Lif 遺伝子（タンパク質 LIF の遺伝子）の転 写を制御していること、p53 欠損型の雌マウスでは子 宮の LIF 発現量が抢よそ4 分の 1 に減少することを見 つけた。 p 53 と LIFの関係を決定づけたのは、交尾 ずみの p53 欠損型雌マウスに LIF を注射すると、着床 が起こり肧は正常に発生し、出産に至った肧の数がか なり増えたことだった。

子宮内ではLIFは主にE2によって制御されている。 着床前は子宮の p 53 量が一定であるとみら机ており、 また、p53 欠損型の雌マウスでの E2 発現量は正常で あることから、p53 はおそらく E2 受容体と複合体を形 


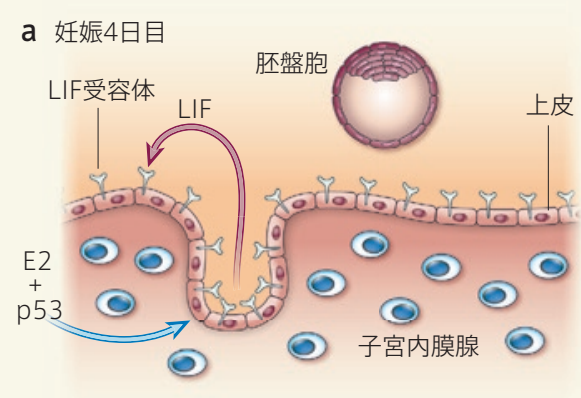

b 妊娠5日目

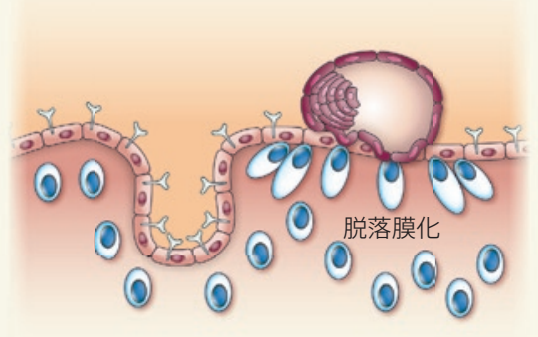

図 1 マウス胚における着床の分子レベルでの制御。a，妊娠 4 日目に、エストロゲンE2 が子宮内膜腺での LIF 発現を誘導し、 LIF が子宮内腔へ分泌され、子宮上皮細胞表面にある受容体に結合する。b，これにより、子宮は胚盤胞の受け入れが可能に なり、胚盤胞が妊娠 5 日目までに着床する。Hu たち ${ }^{2}$ は、子宮内膜腺での LIF の発現が、p53 の制御活性にも依存している ことを見いだした。p53 が存在しないと、LIF の産生量は不十分となり、子宮の受け入れ態勢が十分に整わず、胚盤胞の着床 率は低くなる。

成しているのだろうと Hu たちは考えている。彼らの説 によれば、この複合体は、マウスで妊娠 4 日目に LIF の発現量が最大になるために必要なのだという。

受胎能の制御に p 53 がこのような機能をもつていると は予想外のことであり、通常はストレスによって活性化 される p53 が、なぜ子宮でLif の転写を調節する必要 があるのかは不明である。着床に際して子宮の血管系 は、子宮の細胞増殖（脱落膜化）と肧自身の成長の 両方が進むように支援するため、また低酸素症を防ぐた めに、大がかりな再編を受ける。低酸素症は p53 の活

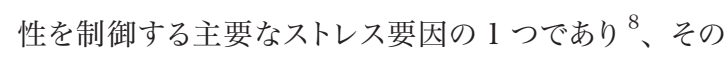
ため、哺乳類の雌の生殖器系が進化するのに伴って、 低酸素症に対応する p53 活性化が「ハイジャック」され、 着床に伴う血管系の変化の調整を助けるようになつたの ではないかとも考えられる。

$\mathrm{Hu}$ たちの知見は、ヒトの繁殖能力とどのような関 連性があるのだろうか。p53 と、その制御因子である Mdm2 などに関する研究から、p53の 72 番目のアミ ノ酸残基にある多型や、Mdm2 の転写制御領域にある 一塩基多型（SNP309）が見つかっている ${ }^{9}$ 。これら の多型はどちらも、p53 の転写活性および発現量に影 響を及ぼしていると考えられている ${ }^{10}$ 。そのため、Hu たちのデータと照らし合わせると、p53 の 72 番目のア ミノ酸残基にある特定の多型（アルギニンがプロリンに
置換）と、再発性着床不全の女性との間に強い相関 がみられること ${ }^{11}$ は興味深い。p 53 の遺伝子多型は、 子宮における p53 の発現量にも影響を与えている可能 性があり、それがさらには LIF 量に影響しているのかも しれない。LIF 量の低下は、ヒトでの着床率の低下と も関係づけられている ${ }^{12}$ 。したがって、Mdm2 におけ るSNP309 多型が、原因不明のヒト不妊症の症例と 関連しているかどうかに興味がもたれる。

腫瘍の成長を抑制するために p53 を制御する小分子 因子を突き止めようと、精力的に研究が続けられている。 そのような分子は、不妊治療の一環として着床率を向 上させるために利用できる可能性があり、さらには、避 妊法の 1 つとして着床の阻害にも使えるかもしれない。

Colin L. Stewart、医学生物学研究所（シンガポール）

1. Donehower, L. A. et al. Nature 356, 215-221 (1992).

2. Hu, W., Feng, Z., Teresky, A. K. \& Levine, A. J. Nature 450, 721-724 (2007),

3. Finn, C. A. \& Martin, L. J. Reprod. Fertil. 39, 195-206 (1974).

4. Dimitriadis, E., White, C. A., Jones, R. L. \& Salamonsen, L. A. Hum. Reprod. Update 11, 613-630 (2005).

5. Cullinan, E. B. et al. Proc. Natl Acad. Sci. USA 93, 3115-3120 (1996).

6. Stewart, C. L. et al. Nature 359, 76-79 (1992).

7. Chen, J. R. et al. Endocrinology 141, 4365-4372 (2000).

8. Graeber, T. G. et al. Nature 379, 88-91 (1996).

9. Bond, G. L. et al. Cell 119, 591-602 (2004).

10. Pietsch, E. C., Humbey, O. \& Murphy, M. E. Oncogene 25, 1602-1611 (2006).

11. Kay, C., Jeyendran, R. S. \& Coulam, C. B. Reprod. Biomed. Online 13, 492-496 (2006).

12. Mikolajczyk, M. et al. Reprod. Biol. 3, 259-270 (2003). 